Review

\title{
A Broad Overview on Pituitary Adenylate Cyclase-Activating Polypeptide Role in the Eye: Focus on Its Repairing Effect in Cornea
}

\author{
Grazia Maugeri ${ }^{1,+}\left(\mathbb{D}\right.$, Agata Grazia $D^{\prime}$ Amico ${ }^{2,+}$ and Velia D'Agata ${ }^{1, *(\mathbb{D})}$ \\ 1 Section of Anatomy, Histology and Movement Sciences, Department of Biomedical and Biotechnological \\ Sciences, University of Catania, 95100 Catania, Italy; graziamaugeri@unict.it \\ 2 Department of Drug Sciences, University of Catania, 95100 Catania, Italy; agata.damico@unict.it \\ * Correspondence: vdagata@unict.it; Tel.: +39-095-378-2147 \\ + These authors contributed equally to this work.
}

check for

updates

Citation: Maugeri, G.; D'Amico, A.G.; D'Agata, V. A Broad Overview on Pituitary Adenylate Cyclase-Activating Polypeptide Role in the Eye: Focus on Its Repairing Effect in Cornea. Appl. Sci. 2022, 12, 760. https://doi.org/ 10.3390/app12020760

Academic Editor: Piotr Minkiewicz

Received: 8 October 2021

Accepted: 10 January 2022

Published: 12 January 2022

Publisher's Note: MDPI stays neutral with regard to jurisdictional claims in published maps and institutional affiliations.

Copyright: (C) 2022 by the authors. Licensee MDPI, Basel, Switzerland. This article is an open access article distributed under the terms and conditions of the Creative Commons Attribution (CC BY) license (https:// creativecommons.org/licenses/by/ $4.0 /)$.

\begin{abstract}
Pituitary Adenylate Cyclase-Activating Polypeptide (PACAP) is a neuropeptide with widespread distribution throughout the central and peripheral nervous system as well as in many other peripheral organs. It plays cytoprotective effects mediated mainly through the activation of specific receptors. PACAP is known to play pleiotropic effects on the eye, including the cornea, protecting it against different types of insult. This review firstly provides an overview of the anatomy of the cornea and summarizes data present in literature about PACAP's role in the eye and, in particular, in the cornea, either in physiological or pathological conditions.
\end{abstract}

Keywords: PACAP; eye; cornea; injury; repair

\section{Introduction}

The cornea, the outermost part of the eye, is a transparent tissue with refractive and barrier functions [1]. Due to the direct connection of the cornea with the external environment, different types of insults, such as chemical, mechanical, and thermal damage, can cause its injury [2]. For this reason, corneal damage represents one of the major causes of blindness worldwide [3]. To date, corneal transplantation represents the most common and successful surgery by restoring good eyesight. However, the high cost, the high graft failure rate, the legal issues, and the lack of donors urge new options for treating, at least, some corneal lesions $[4,5]$.

The neuropeptide pituitary adenylate cyclase-activating polypeptide (PACAP) was isolated for the first time in 1989 from sheep hypothalamic extracts [6]. It exists in two active forms, PACAP27 and PACAP38, including 27 and 38 amino acid residues, respectively, and with mostly comparable functions. PACAP belongs to the vasoactive intestinal polypeptide (VIP)/secretin/glucagon family peptides and shows a high degree of homology ( 70\%) to VIP. PACAP and VIP share three different receptors: the PAC1 receptor (PAC1R), which has a high affinity to PACAP as compared to VIP, and the VPAC1 and VPAC2 receptors, showing a comparable affinity for both peptides [7-10]. Alternative splicing occurring in the PAC1R gene generates different variants (Null, Hip, Hop1, Hop2, Hiphop1, Hiphop2, short and very short isoforms) that can activate the adenylate cyclase (AC) pathway forming cAMP as well as phospholipase $C$ (PLC) pathway promoting the formation of protein kinase C (PKC) [11]. VPAC receptors are coupled to Gs proteins resulting in the activation of AC as well as other signaling cascades [12,13]. Some of the protective effects of PACAP are also mediated by the stimulation of an intracellular factor known as activity-dependent neuroprotective protein (ADNP) [14-16]. In accord, peptide activity scanning identified NAP (NAPVSIPQ), the smallest active element of ADNP, acts in synergy with PACAP by showing neuroprotective effect $[17,18]$. PACAP is widely distributed in the nervous 
system and is consequently implicated in different neurodegenerative diseases [19-26]. In addition, it plays a controversial function in various types of tumors by promoting or inhibiting its progression [27-37]. The protective effects of the peptide were studied not only in the nervous system but also in several peripheral organs and tissue, including the cornea [38-40]. This article provides an overview of the cornea's anatomy and summarizes data present in literature regarding PACAP's role in the cornea either in physiological or pathological conditions by hypothesizing the possibility of its clinical application.

\section{Overview on the Cornea Anatomy}

The human cornea, together with the surrounding sclera, constitutes the protective outer barrier of the eye. In particular, it represents the outer covering of the anterior portion of the eyeball by exerting two essential functions: it protects from external physical trauma and provides about $70 \%$ refractive power of the eye. To perform these functions, the corneal tissue is both mechanically strong and transparent.

The anterior surface of the cornea is convex and aspheric [41]. The cornea comprises five main layers: the epithelium, the Bowman's membrane, the stroma, the Descemet's membrane, and the endothelium [42,43] (Figure 1).

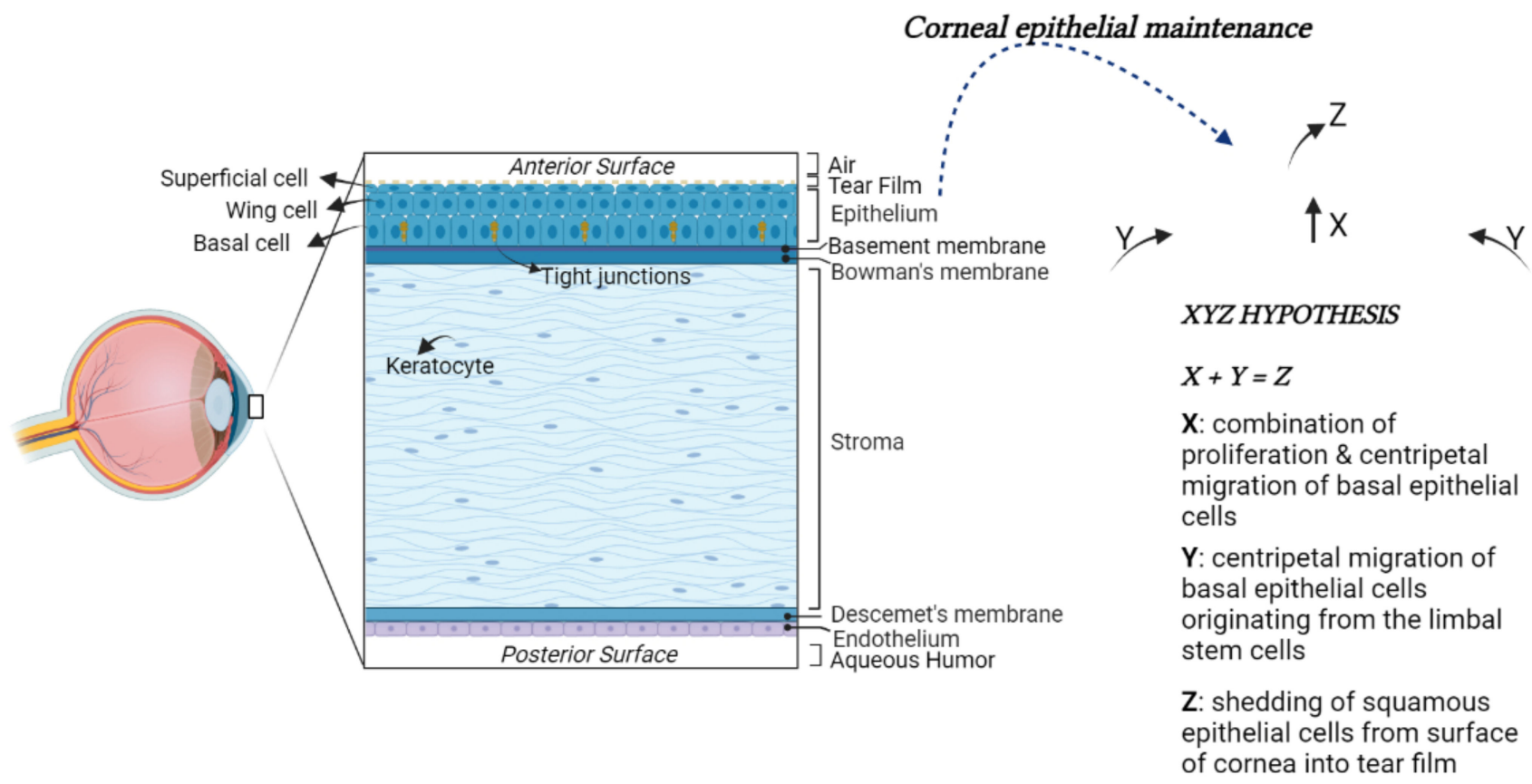

Figure 1. Structural anatomy of the human cornea. From left to right: (1) A diagram of human cornea structure; (2) The XYZ hypothesis. The asymmetric division of LESCs generates a stem-like daughter cell, remaining within the limbus, and a TAC, migrating in a centripetal direction (Y). TACs undergo multiple replications. In this process, they lose stemness, migrate anteriorly and differentiate to post-mitotic suprabasal wing cells $(X)$, and progress in superficial squamous cells, which are lost during normal corneal surface exfoliation $(Z)$ of the epithelial corneal maintenance.

The epithelium represents the outermost layer of the cornea. It originates from the ectoderm overlying the developing lens. The corneal epithelium is approximately $50 \mu \mathrm{m}$ in thickness and is characterized by four to six layers of nonkeratinized stratified squamous epithelial cells. These cells can be morphologically distinguished into the basal columnar, wing, and superficial squamous cells. Basal cells form a monolayer anchored to the underlying basal lamina by hemidesmosomes and filaments. The adjacent cells are tightly joined together with desmosomes and tight junctions by forming a watertight barrier to pathogens entry. The wing cells, so named for their cross-sectional alar shape, originate from basal cells differentiation and are stratified into two or three layers. These cells 
possess tight lateral and intercellular junctions contributing to the structural integrity of the epithelium. Above the wing cell layer, there are two or three nonkeratinized stratified squamous epithelial cell layers. These cells are flat and polygonal in shape with extensive apical microvilli and microplicae covered by a fine glycocalyceal layer that allows the hydrophilic spreading of the tear film every eyelid blink. Laterally, the cells are joined by barrier tight-junctional complexes limiting the access of tears into the intercellular spaces [44].

The corneal epithelium is continuously subjected to a wide range of insults; therefore, its long-term maintenance is regulated by limbal epithelial stem cells (LESCs). The LESCs reside in an annular transition zone known as the limbus, laying at the junction area between the cornea and the sclera. They show typical characteristics of immature and undifferentiated cells [45,46]. In particular, they do not express the cytokeratin 3 and 12, commonly detected in mature, differentiated corneal epithelial cells, whereas they express cytokeratin 14 or TP63, which are stem markers of the immature or progenitor cells in various stratified epithelia. The LESCs give rise to transit-amplifying cells (TACs), which migrate and divide into basal corneal epithelial cells in normal homeostasis conditions or to replace those cells desquamated or lost by lesions (Figure 1) [47,48].

The basement membrane of basal epithelial cells ( $40-60 \mathrm{~nm}$ thickness) is formed by Type IV collagen and laminin. It comprises a lamina lucida and lamina densa. Between the basement membrane and the stroma is located the Bowman's membrane (BM). The BM is composed of randomly oriented collagen fibrils, which help the cornea to maintain its shape [49]. It is approximately 8 to $12 \mu \mathrm{m}$ thickness in humans, but it decreases with age.

The stroma represents the major part of the cornea, comprising approximately more than $80 \%$ of its thickness. Its transparency is the result of the accurate organization of fibers and the extracellular matrix (ECM) [50]. The keratocytes represent the largely distributed stromal cells, with the cell body often localized between stromal lamellae. They exert an important role in maintaining stromal homeostasis by synthesizing collagen, glycosaminoglycans, and matrix metalloproteinases (MMPs). The keratocytes are involved in corneal repair by transforming in a (myo)fibroblast phenotype and releasing growth factors and cytokines [51].

The Descemet's membrane is an acellular, dense, thick, relatively transparent matrix separating the posterior stroma from the underlying endothelium. The endothelial cells continuously secrete Descemet's membrane components, including Type IV collagen and laminin. Descemet's membrane shows an amorphous ultrastructural texture and participates in corneal homeostasis by regulating its hydration.

The endothelium, embryologically deriving from the neural crest, represents the innermost layer of the cornea. It is composed of a $4 \mu \mathrm{m}$ thick monolayer of flat cells with a polygonal shape. It maintains tissue hydration and transparency, acting both as a barrier and functional pump, generating an osmotic gradient to keep the relative stromal deturgescence [52]. As a barrier, the corneal endothelium avoids the facile solutes permeability and fluid leak through the paracellular route. To absolve this role, its upper surface adheres to Descemet's membrane through hemidesmosomes and tight junctions localized in the apical side of the endothelial cells. To control the transport of water, glucose, and other solutes from aqueous humor to the stroma, the endothelial cell membrane contains aquaporins (AQP) as well as $\mathrm{Na}^{+} / \mathrm{K}^{+}$ATPase pump, both participating in the fluid movement across the endothelium [53]. In adults, the average density of corneal endothelial cells (HCECs) is $\sim 3000$ cells $/ \mathrm{mm}^{2}$, and the percentage of hexagonal cells is about $75 \%$. However, their loss due to aging, diseases, injury, or surgery may induce severe transparency corneal alteration since they have limited proliferative capability [54]. In the adult cornea, HCECs are, in fact, arrested in the G1 phase of the cell cycle due to contact inhibition among them as well as a lack of valid growth factor stimulation and other contributing causes. To maintain proper endothelium structure and function, HCECs respond to minor damage by enlarging and invading the injured area [55]. However, the 
increase in cell size (polymegathism) and alteration of their morphology (pleomorphism) reduce their ability to maintain corneal hydration.

\section{Role of PACAP and Its Receptors in the Eye}

The presence of PACAP and its receptors has been largely shown in the eye $[33,56]$. PACAP positive expression was found in mammalian, teleost, turtle, and chicken retina [57]. In particular, in situ hybridization and immunohistochemical analysis have revealed the presence of PACAP in specific cell populations of retinal tissue samples. PACAP was positively expressed in the nerve fiber layer (NFL), the ganglion cell layer (GCL), the inner plexiform layer (IPL), and the pigment epithelium (PE). The immunoreactivity of PACAP appeared in the early phase of retinal development [58], as demonstrated by its presence in the chick inner nuclear layer (INL) from embryonic day 8 [59]. PACAP mRNA expression was detectable in the rat GCL at embryonic day 20 [60], whereas, in the zebrafish, PACAP immune-positive signal was found in the retina at $24 \mathrm{~h}$ post-fertilization [61]. PAC1R was strongly expressed in the GCL, in neuronal cell bodies of amacrine and horizontal cells localized in the INL and in the PE. On the contrary, PAC1R was weakly expressed in the IPL, outer plexiform layer (OPL), outer nuclear layer (ONL), and photoreceptor layer [62-65]. The expression profile of PAC1R splice variants (Null, Hip, Hop1, Hop2, Hiphop1, and Hiphop2) was described during retina development [11]. The expression of PAC1Rs at the subcellular level was identified at the plasma membrane, in the rough endoplasmic reticulum, in the cytoplasmic matrix of retinal ganglion cells (RGCs) and amacrine cells in the INL [66]. PAC1R immunoreactivity was also detected in retinal tissue and in rat primary cultures of Müller cells $[67,68]$. In the rat retina, the expression of VPAC1R and VPAC2R was demonstrated [69]. Moreover, Lakk et al. [11] showed the potential involvement of VPACRs at all stages of retinal development in the rat.

The protective effects of PACAP in the visual system have been widely studied in the neural and non-neuronal parts of the eye, including the cornea (Figure 2).

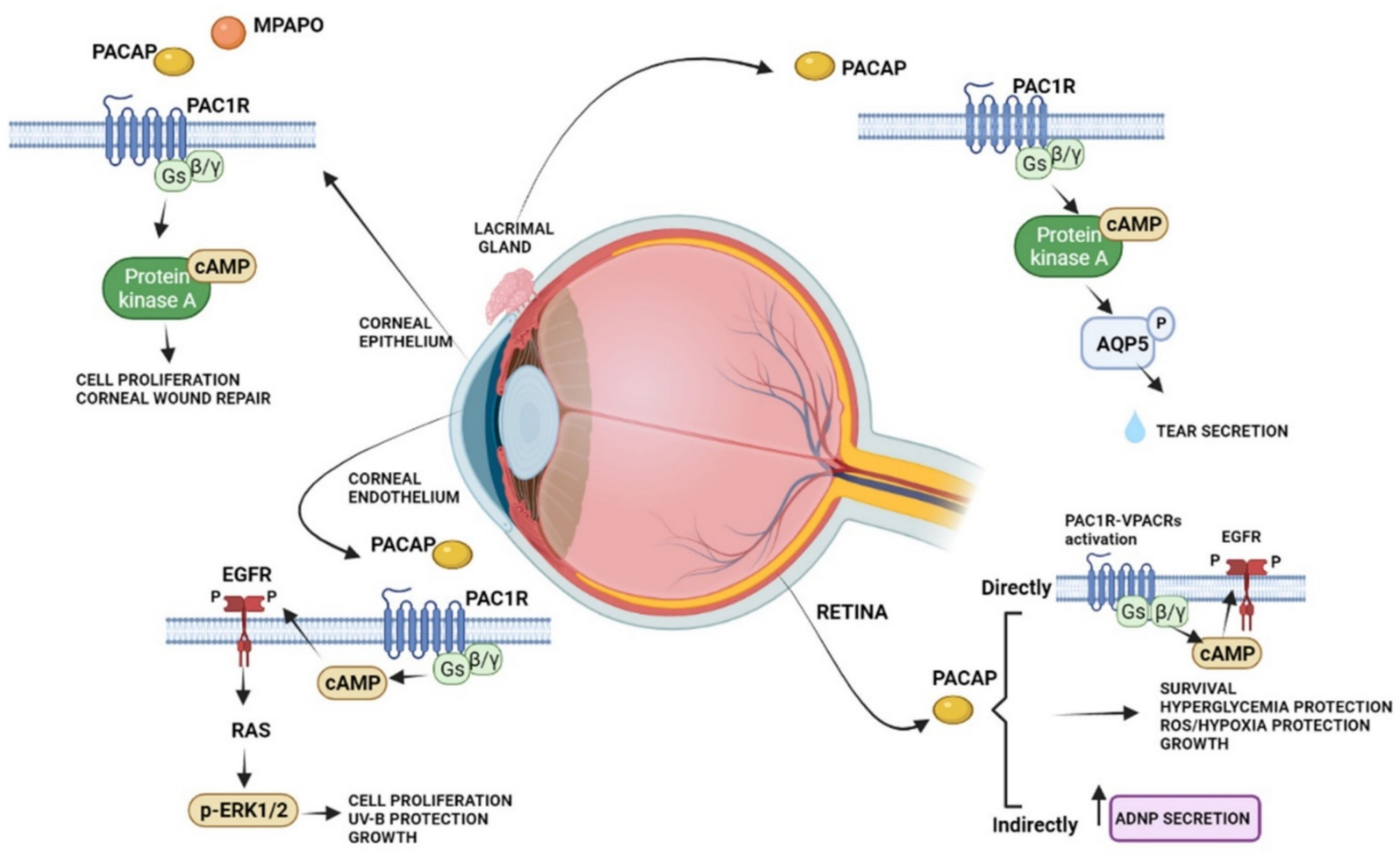

Figure 2. Schematic diagram showing the main pro-survival/antiapoptotic/protective intracellular pathways activated by PACAP in different ocular structures. 
Several studies showed that PACAP has protective effects in the retina against toxic or ischemic insults, inflammation, hypoxia, oxygen-induced retinopathy, traumatic injuries, glaucoma, and diabetic retinopathy [70-81]. The protective role of PACAP was observed in different cell types, including bipolar neurons, amacrine, and pigment epithelial cells [82,83]. In particular, in the retinal pigment epithelial cells, PACAP counteracted oxidative stress and hypoxic insult by exerting protective and pro-survival effects [83-86].

PACAP is also expressed in a subpopulation of retinal ganglion cells participating in the modulation of the circadian rhythm through a photoneuroendocrine circuit. In fact, it transfers light signals from the retina to the suprachiasmatic nucleus via the retinohypothalamic tract [87]. In accord, it has been shown that the intracerebroventricular injection of PACAP induced a phase-delay of the circadian rhythm similarly to light and the treatment with PACAP receptor antagonist reduced light changes in vitro [88]. This evidence let hypothesized that exogenous administration of PACAP as a repair agent for damage to the structure of the eye might alter the wake-sleep cycle. PACAP is not only expressed in the retina, but it has also been demonstrated in other ocular tissues. A rich plexus of PACAP-immunoreactive nerve fibers were found in the cat lacrimal gland, arising mainly from the sphenopalatine ganglion, where $10 \%$ of the neuronal cell bodies show PACAP immunoreactivity [89]. Moreover, PAC1R immunoreactivity was observed in mouse infraorbital lacrimal gland acinar cells [90]. Here, PACAP eye drops promoted tear secretion via the PAC1R/AC/cAMP/PKA/AQP5 cascade [91]. PACAP receptors were found in both the anterior uvea and choroid [92]. Interestingly, the intravenous infusion of PACAP reduced the uveal vascular resistance and increased the choroidal blood flow, suggesting its involvement in eye regional blood flow regulation [92]. Accordingly, different studies showed that PACAP, whose immunoreactivity was detected in the supraoptic nucleus and paraventricular nucleus [93], stimulates vasopressin release from isolated neurointermediate lobes of the pituitary gland [94].

PACAP immunoreactive nerve fibers were found in the conjunctiva, ciliary body, and iris $[89,95]$. PACAP-like immunoreactivity was detected into the aqueous humor following a noxious stimulus, and the peptide also caused tachykinin-mediated contractions of the isolated iris sphincter muscle, indicating that the peptide induces positive feedback on sensory C-fibers [95]. In accord, Yoshitomi et al. [96] showed that PACAP treatment induces the cholinergic transmission in the iris sphincter muscle. In particular, the peptide promotes the relaxation of the dilator muscle by a direct effect on it. Therefore, it has been also hypothesized that the miosis occurring during ocular inflammation may be due, at least in part, to PACAP released from the trigeminal fibers innervating the eye [97].

\section{The Role of PACAP in the Cornea}

The expression of PACAP and its receptors has been shown in the cornea. Here, PACAP positive cells were found in rabbit and human corneal epithelium, particularly in the basal cells. Moreover, the expression of PACAP was detected in the corneal endothelial layer and weakly in the stroma [98,99]. High expression levels of PAC1R were identified in the stromal and basal cells of the epithelium. Furthermore, the VPACRs were strongly expressed in all layers of the epithelium and in stromal cells of the rabbit cornea [99]. Previously, Wang [95] et al. detected PACAP immunoreactivity in nerve terminals running in the stroma and sending off some branches into the epithelium. Corneal injury is frequently associated with damage of the epithelium and its innervating fibers. In an in vivo experimental model of laser-assisted in situ keratomileuses (LASIK) surgery, PACAP showed to accelerate recovery of corneal sensitivity after the creation of a corneal flap. In more detail, the administration of $10 \mu \mathrm{M}$ PACAP27 increased up to $75 \%$ the corneal sensitivity eight weeks after the operation [100]. In accord, it has been demonstrated that PACAP induced the growth of neuronal processes in cultured trigeminal ganglion cells. These neurons secrete various biologically active molecules enhancing the proliferation and differentiation of corneal epithelial cells as well as collagen VII production, important to maintaining and repairing the corneal epithelium [101]. The protective effect of PACAP was confirmed by 
Wu et al., 2015 [102], by showing that the peptide alone or in combination with the receptor protein of laminin, known as $\mathrm{N}$-terminal agrin domain (NtA), significantly accelerated the process of repairing the mechanically injured corneal epithelial cells. It is well known that tear fluid contains different antibacterial proteins, growth factors, and secretory mucin important for corneal maintenance and its repairing [101,103]. For this reason, tear fluid reduction, occurring in dry eye syndrome, is an inducing factor in corneal keratinization. PACAP played an important role in protecting the corneal surface by stimulating tear secretion [104]. As described above, in the lacrimal gland, PACAP is an endogenous modulator of AQP5, involved in tear production [90]. In accord, PACAP null mice showed a reduction in the AQP5 expression, whereas the eye treatment with PACAP drops stimulated its transcription. Furthermore, PACAP null mice exhibited the dry eye syndrome phenotype with a corneal disorder associated with the reduction in tear volume [90].

Although PACAP has been shown to promote corneal repair, including epithelial and nerve regeneration, therapeutic use of the peptide presents some limitations. In fact, it has poor in vivo stability, with a half-life of fewer than ten minutes, due to its fast degradation by the proteolytic enzyme dipeptidyl peptidase IV [105]. A very recent study [106] compared the stability of PACAP1-27 and PACAP1-38 in four common media and a commercially available artificial tear solution either at room temperature or $+4{ }^{\circ} \mathrm{C}$. The results showed that PACAP1-38 has higher stability as compared to PACAP1-27, mainly at $+4{ }^{\circ} \mathrm{C}$ in water solution. Moreover, both peptides can be stored in each medium for relatively long periods without significant degradation. These results suggested a therapeutic use of PACAP in eye drops. In a previous study, Ma [107] et al. have synthesized a new PACAP agonist, known as PACAP27-derived mutant peptide (MPAPO), and tested its efficacy either in vitro or in vivo model of corneal damage [108]. The study was performed on C57BL/ 6 mice by performing a whole corneal epithelium wound through the use of a trephine. The treatment with MPAPO significantly promoted corneal epithelial wound closure after $36 \mathrm{~h}$ from the administration. At $48 \mathrm{~h}$ after administration, the intact structure of the whole cornea was clearly observable through hematoxylin and eosin staining from the dense epithelial cell layer until the endothelial corneal layer. Moreover, either PACAP27 or MPAPO promoted axonal regeneration in the cornea after injury by reporting innervation patterns comparable to the control group. To investigate the mechanism of action of this peptide, the authors tested the MPAPO effect on $\mathrm{H} 2 \mathrm{O} 2$-injured corneal epithelial cells. The peptide promoted cell proliferation through the activation of the cAMP/PKA signaling pathway.

The protective effect of PACAP was also demonstrated on the corneal endothelium. Maugeri [24] et al. showed, for the first time, the expression of PACAP and PAC1R in the inner layer of the human cornea. In human corneal endothelial cells (HCECs) derived from differentiating stem cells of donors' cornea, the treatment with PACAP promoted cell viability, barrier integrity, and wound repairing induced on the corneal endothelial cell monolayer deprived of growth factors [99]. The molecular mechanism mediating the trophic function of PACAP was linked to the phosphorylation of the epidermal growth factor receptor (EGFR), which, in turn, promoted the MAPK/ERK1/2 signaling pathway activation [24]. The ability of the peptide to cause EGFR phosphorylation was largely demonstrated. Indeed, PACAP-induced EGFR transactivation was observed in neurons, in lung cancer cells, in an in vitro model of amyotrophic lateral sclerosis, and in an in vitro and in vivo model of diabetic retinopathy [109-112]. PACAP also affected the HCECs exposed to UV-B radiation damage by promoting the formation of new tight-junction among them to ensure barrier integrity, as well as a regular fluid passage through the paracellular route from the anterior camera to the upper corneal layers [113]. Despite all of the evidence that demonstrated PACAP protective and regenerative effects, previous papers have highlighted that the peptide could be involved in ocular inflammation. In fact, electroconvulsive treatment, as well as other noxious stimuli, increased PACAP immunoreactivity in the aqueous humor of rabbits $[114,115]$. Furthermore, the expression of PACAP in sensory neurons confirms its active role in neurogenic inflammation response [116-118]. These 
opposing effects are caused by the contribution of all three PACAP receptors and their respective heterodimers or splice variants.

\section{Conclusions}

The direct contact of the cornea with the external environment makes it frequently exposed to various types of injuries. The surgical replacement of lesioned cornea with healthy donor tissue is the frequently used therapeutic approach. To date, the actual challenge is linked to recruiting a sufficient number of donors, requiring alternatives to decrease this persistent demand. PACAP has shown important corneal protective and regenerative effects. Therefore, the development of innovative nanoformulation platforms for topical PACAP or PAC1R agonists delivery, as well as the synthesis of molecules able to increase PACAP endogenous expression, might represent a valid strategy for the treatment of some corneal diseases.

Author Contributions: Conceptualization, G.M. and V.D.; writing—original draft preparation, G.M., A.G.D. and V.D. writing-review and editing, G.M., A.G.D. and V.D.; supervision, V.D.; funding acquisition, G.M. and A.G.D. All authors have read and agreed to the published version of the manuscript.

Funding: This research was funded by PIAno di inCEntivi per la RIcerca di Ateneo 2020/2022 Linea di Intervento 3 "Starting Grant" "REPAIR", University of Catania.

Institutional Review Board Statement: Not applicable.

Informed Consent Statement: Not applicable.

Conflicts of Interest: The authors declare no conflict of interest.

\section{References}

1. Avadhanam, V.S.; Liu, C.S. A brief review of Boston type-1 and osteo-odonto keratoprostheses. Br. J. Ophthalmol. 2015, 99, 878-887. [CrossRef] [PubMed]

2. Han, Y.; Li, X.; Zhang, Y.; Han, Y.; Chang, F.; Ding, J. Mesenchymal Stem Cells for Regenerative Medicine. Cells 2019, 8, 886. [CrossRef] [PubMed]

3. Flaxman, S.R.; Bourne, R.R.A.; Resnikoff, S.; Ackland, P.; Braithwaite, T.; Cicinelli, M.V.; Das, A.; Jonas, J.B.; Keeffe, J.; Kempen, J.H.; et al. Global causes of blindness and distance vision impairment 1990-2020: A systematic review and metaanalysis. Lancet Glob. Health 2017, 5, e1221-e1234. [CrossRef]

4. Gain, P.; Jullienne, R.; He, Z.; Aldossary, M.; Acquart, S.; Cognasse, F.; Thuret, G. Global Survey of Corneal Transplantation and Eye Banking. JAMA Ophthalmol. 2016, 134, 167-173. [CrossRef] [PubMed]

5. Golchet, G.; Carr, J.; Harris, M.G. Why don't we have enough cornea donors? A literature review and survey. Optometry 2000, 71, 318-328. [PubMed]

6. Miyata, A.; Arimura, A.; Dahl, R.R.; Minamino, N.; Uehara, A.; Jiang, L.; Culler, M.D.; Coy, D.H. Isolation of a novel 38 residue-hypothalamic polypeptide which stimulates adenylate cyclase in pituitary cells. Biochem. Biophys. Res. Commun. 1989, 164, 567-574. [CrossRef]

7. Arimura, A. Pituitary adenylate cyclase activating polypeptide (PACAP): Discovery and current status of research. Regul. Pept. 1992, 37, 287-303. [CrossRef]

8. Arimura, A.; Shioda, S. Pituitary adenylate cyclase activating polypeptide (PACAP) and its receptors: Neuroendocrine and endocrine interaction. Front. Neuroendocrinol. 1995, 16, 53-88. [CrossRef]

9. Sherwood, N.M.; Krueckl, S.L.; McRory, J.E. The origin and function of the pituitary adenylate cyclase-activating polypeptide (PACAP)/glucagon superfamily. Endocr. Rev. 2000, 21, 619-670. [CrossRef]

10. Harmar, A.J.; Fahrenkrug, J.; Gozes, I.; Laburthe, M.; May, V.; Pisegna, J.R.; Vaudry, D.; Vaudry, H.; Waschek, J.A.; Said, S.I. Pharmacology and functions of receptors for vasoactive intestinal peptide and pituitary adenylate cyclase-activating polypeptide: IUPHAR review 1. Br. J. Pharmacol. 2012, 166, 4-17. [CrossRef]

11. Dickson, L.; Finlayson, K. VPAC and PAC receptors: From ligands to function. Pharmacol. Ther. 2009, 121, 294-316. [CrossRef]

12. Somogyvári-Vigh, A.; Reglodi, D. Pituitary adenylate cyclase activating polypeptide: A potential neuroprotective peptide. Curr. Pharm. Des. 2004, 10, 2861-2889. [CrossRef]

13. Shioda, S.; Ohtaki, H.; Nakamachi, T.; Dohi, K.; Watanabe, J.; Nakajo, S.; Arata, S.; Kitamura, S.; Okuda, H.; Takenoya, F.; et al. Pleiotropic functions of PACAP in the CNS: Neuroprotection and neurodevelopment. Ann. N. Y. Acad. Sci. 2006, 1070, 550-560. [CrossRef] 
14. Bassan, M.; Zamostiano, R.; Davidson, A.; Pinhasov, A.; Giladi, E.; Perl, O.; Bassan, H.; Blat, C.; Gibney, G.; Glazner, G.; et al. Complete sequence of a novel protein containing a femtomolar-activity-dependent neuroprotective peptide. J. Neurochem. 1999, 72, 1283-1293. [CrossRef]

15. Zamostiano, R.; Pinhasov, A.; Gelber, E.; Steingart, R.A.; Seroussi, E.; Giladi, E.; Bassan, M.; Wollman, Y.; Eyre, H.J.; Mulley, J.C.; et al. Cloning and characterization of the human activity-dependent neuroprotective protein. J. Biol. Chem. 2001, 276, 708-714. [CrossRef]

16. D'Amico, A.G.; Maugeri, G.; Musumeci, G.; Reglodi, D.; D'Agata, V. PACAP and NAP: Effect of Two Functionally Related Peptides in Diabetic Retinopathy. J. Mol. Neurosci. 2021, 71, 1525-1535. [CrossRef]

17. D'Amico, A.G.; Maugeri, G.; Rasà, D.; Federico, C.; Saccone, S.; Lazzara, F.; Fidilio, A.; Drago, F.; Bucolo, C.; D'Agata, V. NAP modulates hyperglycemic-inflammatory event of diabetic retina by counteracting outer blood retinal barrier damage. J. Cell. Physiol. 2019, 234, 5230-5240. [CrossRef]

18. D'Amico, A.G.; Scuderi, S.; Maugeri, G.; Cavallaro, S.; Drago, F.; D'Agata, V. NAP reduces murine microvascular endothelial cells proliferation induced by hyperglycemia. J. Mol. Neurosci. 2014, 54, 405-413. [CrossRef]

19. Solés-Tarrés, I.; Cabezas-Llobet, N.; Vaudry, D.; Xifró, X. Protective Effects of Pituitary Adenylate Cyclase-Activating Polypeptide and Vasoactive Intestinal Peptide against Cognitive Decline in Neurodegenerative Diseases. Front. Cell. Neurosci. 2020, 14, 221. [CrossRef]

20. Dejda, A.; Jolivel, V.; Bourgault, S.; Seaborn, T.; Fournier, A.; Vaudry, H.; Vaudry, D. Inhibitory effect of PACAP on caspase activity in neuronal apoptosis: A better understanding towards therapeutic applications in neurodegenerative diseases. J. Mol. Neurosci. 2008, 36, 26-37. [CrossRef]

21. Reglodi, D.; Kiss, P.; Lubics, A.; Tamas, A. Review on the protective effects of PACAP in models of neurodegenerative diseases in vitro and in vivo. Curr. Pharm. Des. 2011, 17, 962-972. [CrossRef] [PubMed]

22. Waschek, J.A. VIP and PACAP: Neuropeptide modulators of CNS inflammation, injury, and repair. Br. J. Pharmacol. 2013, 169, 512-523. [CrossRef] [PubMed]

23. D’Amico, A.G.; Maugeri, G.; Saccone, S.; Federico, C.; Cavallaro, S.; Reglodi, D.; D’Agata, V. PACAP Modulates the Autophagy Process in an In Vitro Model of Amyotrophic Lateral Sclerosis. Int. J. Mol. Sci. 2020, 21, 2943. [CrossRef] [PubMed]

24. Maugeri, G.; D'Amico, A.G.; Castrogiovanni, P.; Saccone, S.; Federico, C.; Reibaldi, M.; Russo, A.; Bonfiglio, V.; Avitabile, T.; Longo, A.; et al. PACAP through EGFR transactivation preserves human corneal endothelial integrity. J. Cell. Biochem. 2019, 120, 10097-10105. [CrossRef]

25. Maugeri, G.; D'Amico, A.G.; Morello, G.; Reglodi, D.; Cavallaro, S.; D'Agata, V. Differential Vulnerability of Oculomotor Versus Hypoglossal Nucleus During ALS: Involvement of PACAP. Front. Neurosci. 2020, 14, 805. [CrossRef]

26. Maugeri, G.; D’Amico, A.G.; Musumeci, G.; Reglodi, D.; D'Agata, V. Effects of Pacap on Schwann Cells: Focus on Nerve Injury. Int. J. Mol. Sci. 2020, 21, 8233. [CrossRef]

27. Moody, T.W.; Nuche-Berenguer, B.; Jensen, R.T. Vasoactive intestinal peptide/pituitary adenylate cyclase activating polypeptide, and their receptors and cancer. Curr. Opin. Endocrinol. Diabetes Obes. 2016, 23, 38-47. [CrossRef]

28. D'Amico, A.G.; Maugeri, G.; Bucolo, C.; Saccone, S.; Federico, C.; Cavallaro, S.; D'Agata, V. Nap Interferes with Hypoxia-Inducible Factors and VEGF Expression in Retina of Diabetic Rats. J. Mol. Neurosci. 2017, 61, 256-266. [CrossRef]

29. Maugeri, G.; D’Amico, A.G.; Rasà, D.M.; Saccone, S.; Federico, C.; Cavallaro, S.; D'Agata, V. PACAP and VIP regulate hypoxiainducible factors in neuroblastoma cells exposed to hypoxia. Neuropeptides 2018, 69, 84-91. [CrossRef]

30. Maugeri, G.; D’Amico, A.G.; Reitano, R.; Magro, G.; Cavallaro, S.; Salomone, S.; D'Agata, V. PACAP and VIP Inhibit the Invasiveness of Glioblastoma Cells Exposed to Hypoxia through the Regulation of HIFs and EGFR Expression. Front. Pharmacol. 2016, 7, 139. [CrossRef]

31. Ferencz, S.; Reglodi, D.; Kaszas, B.; Bardosi, A.; Toth, D.; Vekony, Z.; Vicena, V.; Karadi, O.; Kelemen, D. PACAP and PAC1 receptor expression in pancreatic ductal carcinoma. Oncol. Lett. 2019, 18, 5725-5730. [CrossRef]

32. Bensalma, S.; Turpault, S.; Balandre, A.C.; De Boisvilliers, M.; Gaillard, A.; Chadéneau, C.; Muller, J.M. PKA at a Cross-Road of Signaling Pathways Involved in the Regulation of Glioblastoma Migration and Invasion by the Neuropeptides VIP and PACAP. Cancers 2019, 11, 123. [CrossRef]

33. Cavallaro, S.; D'Agata, V.; Guardabasso, V.; Travali, S.; Stivala, F.; Canonico, P.L. Differentiation induces pituitary adenylate cyclase-activating polypeptide receptor expression in PC-12 cells. Mol. Pharmacol. 1995, 48, 56-62.

34. Castorina, A.; Giunta, S.; Scuderi, S.; D'Agata, V. Involvement of PACAP/ADNP signaling in the resistance to cell death in malignant peripheral nerve sheath tumor (MPNST) cells. J. Mol. Neurosci. 2012, 48, 674-683. [CrossRef]

35. Castorina, A.; Scuderi, S.; D'Amico, A.G.; Drago, F.; D'Agata, V. PACAP and VIP increase the expression of myelin-related proteins in rat schwannoma cells: Involvement of PAC1/VPAC2 receptor-mediated activation of PI3K/Akt signaling pathways. Exp. Cell Res. 2014, 322, 108-121. [CrossRef]

36. Castorina, A.; Tiralongo, A.; Giunta, S.; Carnazza, M.L.; Rasi, G.; D'Agata, V. PACAP and VIP prevent apoptosis in schwannoma cells. Brain Res. 2008, 1241, 29-35. [CrossRef]

37. D'Amico, A.G.; Scuderi, S.; Saccone, S.; Castorina, A.; Drago, F.; D'Agata, V. Antiproliferative effects of PACAP and VIP in serum-starved glioma cells. J. Mol. Neurosci. 2013, 51, 503-513. [CrossRef] 
38. Maino, B.; D’Agata, V.; Severini, C.; Ciotti, M.T.; Calissano, P.; Copani, A.; Chang, Y.C.; DeLisi, C.; Cavallaro, S. Igf1 and Pacap rescue cerebellar granule neurons from apoptosis via a common transcriptional program. Cell Death Discov. 2015, 1, 15029. [CrossRef]

39. Toth, D.; Szabo, E.; Tamas, A.; Juhasz, T.; Horvath, G.; Fabian, E.; Opper, B.; Szabo, D.; Maugeri, G.; D’Amico, A.G.; et al. Protective Effects of PACAP in Peripheral Organs. Front. Endocrinol. 2020, 11, 377. [CrossRef]

40. D'Agata, V.; Cavallaro, S.; Stivala, F.; Canonico, P.L. Tissue-specific and developmental expression of pituitary adenylate cyclase-activating polypeptide (PACAP) receptors in rat brain. Eur. J. Neurosci. 1996, 8, 310-318. [CrossRef]

41. Feizi, S.; Jafarinasab, M.R.; Karimian, F.; Hasanpour, H.; Masudi, A. Central and peripheral corneal thickness measurement in normal and keratoconic eyes using three corneal pachymeters. J. Ophthalmic Vis. Res. 2014, 9, 296-304.

42. Patel, S.; McLaren, J.; Hodge, D.; Bourne, W. Normal human keratocyte density and corneal thickness measurement by using confocal microscopy in vivo. Investig. Ophthalmol. Vis. Sci. 2001, 42, 333-339.

43. Reinstein, D.Z.; Archer, T.J.; Gobbe, M.; Silverman, R.H.; Coleman, D.J. Stromal thickness in the normal cornea: Three-dimensional display with artemis very high-frequency digital ultrasound. J. Refract. Surg. 2009, 25, 776-786. [CrossRef]

44. Ban, Y.; Dota, A.; Cooper, L.J.; Fullwood, N.J.; Nakamura, T.; Tsuzuki, M.; Mochida, C.; Kinoshita, S. Tight junction-related protein expression and distribution in human corneal epithelium. Exp. Eye Res. 2003, 76, 663-669. [CrossRef]

45. Dziasko, M.A.; Daniels, J.T. Anatomical Features and Cell-Cell Interactions in the Human Limbal Epithelial Stem Cell Niche. Ocul. Surf. 2016, 14, 322-330. [CrossRef]

46. Notara, M.; Alatza, A.; Gilfillan, J.; Harris, A.R.; Levis, H.J.; Schrader, S.; Vernon, A.; Daniels, J.T. In sickness and in health: Corneal epithelial stem cell biology, pathology and therapy. Exp. Eye Res. 2010, 90, 188-195. [CrossRef]

47. Dorà, N.J.; Hill, R.E.; Collinson, J.M.; West, J.D. Lineage tracing in the adult mouse corneal epithelium supports the limbal epithelial stem cell hypothesis with intermittent periods of stem cell quiescence. Stem Cell Res. 2015, 15, 665-677. [CrossRef]

48. Thoft, R.A.; Friend, J. The X, Y, Z hypothesis of corneal epithelial maintenance. Investig. Ophthalmol. Vis. Sci. 1983, 24, 1442-1443.

49. Dewitt, E.N. The Histopathology of Bowman's Membrane. Trans. Am. Ophthalmol. Soc. 1931, 29, 461-485.

50. Bron, A.J. The architecture of the corneal stroma. Br. J. Ophthalmol. 2001, 85, 379-381. [CrossRef]

51. West-Mays, J.A.; Dwivedi, D.J. The keratocyte: Corneal stromal cell with variable repair phenotypes. Int. J. Biochem. Cell Biol. 2006, 38, 1625-1631. [CrossRef] [PubMed]

52. Bourne, W.M. Biology of the corneal endothelium in health and disease. Eye 2003, 17, 912-918. [CrossRef] [PubMed]

53. Verkman, A.S. Role of aquaporin water channels in eye function. Exp. Eye Res. 2003, 76, 137-143. [CrossRef]

54. Joyce, N.C. Proliferative capacity of corneal endothelial cells. Exp. Eye Res. 2012, 95, 16-23. [CrossRef]

55. Sheng, H.; Bullimore, M.A. Factors affecting corneal endothelial morphology. Cornea 2007, 26, 520-525. [CrossRef]

56. Atlasz, T.; Szabadfi, K.; Kiss, P.; Racz, B.; Gallyas, F.; Tamas, A.; Gaal, V.; Marton, Z.; Gabriel, R.; Reglodi, D. Pituitary adenylate cyclase activating polypeptide in the retina: Focus on the retinoprotective effects. Ann. N. Y. Acad. Sci. 2010, 1200, 128-139. [CrossRef]

57. Reglödi, D.; Somogyvári-Vigh, A.; Vígh, J.; Li, M.; Lengvári, I.; Arimura, A. Pituitary adenylate cyclase activating polypeptide is highly abundant in the nervous system of anoxia-tolerant turtle, Pseudemys scripta elegans. Peptides 2001, 22, 873-878. [CrossRef]

58. Fahrenkrug, J.; Nielsen, H.S.; Hannibal, J. Expression of melanopsin during development of the rat retina. Neuroreport 2004, 15, 781-784. [CrossRef]

59. Borba, J.C.; Henze, I.P.; Silveira, M.S.; Kubrusly, R.C.; Gardino, P.F.; de Mello, M.C.; Hokoç, J.N.; de Mello, F.G. Pituitary adenylate cyclase-activating polypeptide (PACAP) can act as determinant of the tyrosine hydroxylase phenotype of dopaminergic cells during retina development. Dev. Brain Res. 2005, 156, 193-201. [CrossRef]

60. Skoglösa, Y.; Takei, N.; Lindholm, D. Distribution of pituitary adenylate cyclase activating polypeptide mRNA in the developing rat brain. Brain Research. Mol. Brain Res. 1999, 65, 1-13. [CrossRef]

61. Mathieu, M.; Ciarlo, M.; Trucco, N.; Griffero, F.; Damonte, G.; Salis, A.; Vallarino, M. Pituitary adenylate cyclase-activating polypeptide in the brain, spinal cord and sensory organs of the zebrafish, Danio rerio, during development. Dev. Brain Res. 2004, 151, 169-185. [CrossRef]

62. Seki, T.; Shioda, S.; Ogino, D.; Nakai, Y.; Arimura, A.; Koide, R. Distribution and ultrastructural localization of a receptor for pituitary adenylate cyclase activating polypeptide and its mRNA in the rat retina. Neurosci. Lett. 1997, 238, 127-130. [CrossRef]

63. Seki, T.; Shioda, S.; Nakai, Y.; Arimura, A.; Koide, R. Distribution and ultrastructural localization of pituitary adenylate cyclaseactivating polypeptide (PACAP) and its receptor in the rat retina. Ann. N. Y. Acad. Sci. 1998, 865, 408-411. [CrossRef]

64. Seki, T.; Izumi, S.; Shioda, S.; Zhou, C.J.; Arimura, A.; Koide, R. Gene expression for PACAP receptor mRNA in the rat retina by in situ hybridization and in situ RT-PCR. Ann. N. Y. Acad. Sci. 2000, 921, 366-369. [CrossRef]

65. Seki, T.; Shioda, S.; Izumi, S.; Arimura, A.; Koide, R. Electron microscopic observation of pituitary adenylate cyclase-activating polypeptide (PACAP)-containing neurons in the rat retina. Peptides 2000, 21, 109-113. [CrossRef]

66. Nakamachi, T.; Matkovits, A.; Seki, T.; Shioda, S. Distribution and protective function of pituitary adenylate cyclase-activating polypeptide in the retina. Front. Endocrinol. 2012, 3, 145. [CrossRef]

67. Dénes, V.; Czotter, N.; Lakk, M.; Berta, G.; Gábriel, R. PAC1-expressing structures of neural retina alter their PAC1 isoform splicing during postnatal development. Cell Tissue Res. 2014, 355, 279-288. [CrossRef]

68. Seki, T.; Hinohara, Y.; Taki, C.; Nakatani, M.; Ozawa, M.; Nishimura, S.; Takaki, A.; Itho, H.; Takenoya, F.; Shioda, S. PACAP stimulates the release of interleukin-6 in cultured rat Müller cells. Ann. N. Y. Acad. Sci. 2006, 1070, 535-539. [CrossRef] 
69. D'Agata, V.; Cavallaro, S. Functional and molecular expression of PACAP/VIP receptors in the rat retina. Mol. Brain Res. 1998, 54, 161-164. [CrossRef]

70. Atlasz, T.; Werling, D.; Song, S.; Szabo, E.; Vaczy, A.; Kovari, P.; Tamas, A.; Reglodi, D.; Yu, R. Retinoprotective Effects of TAT-Bound Vasoactive Intestinal Peptide and Pituitary Adenylate Cyclase Activating Polypeptide. J. Mol. Neurosci. 2019, 68, 397-407. [CrossRef]

71. Ye, D.; Shi, Y.; Xu, Y.; Huang, J. PACAP Attenuates Optic Nerve Crush-Induced Retinal Ganglion Cell Apoptosis Via Activation of the CREB-Bcl-2 Pathway. J. Mol. Neurosci. 2019, 68, 475-484. [CrossRef]

72. Ye, D.; Yang, Y.; Lu, X.; Xu, Y.; Shi, Y.; Chen, H.; Huang, J. Spatiotemporal Expression Changes of PACAP and Its Receptors in Retinal Ganglion Cells After Optic Nerve Crush. J. Mol. Neurosci. 2019, 68, 465-474. [CrossRef]

73. Seki, T.; Itoh, H.; Nakamachi, T.; Shioda, S. Suppression of ganglion cell death by PACAP following optic nerve transection in the rat. J. Mol. Neurosci. 2008, 36, 57-60. [CrossRef]

74. Endo, K.; Nakamachi, T.; Seki, T.; Kagami, N.; Wada, Y.; Nakamura, K.; Kishimoto, K.; Hori, M.; Tsuchikawa, D.; Shinntani, N.; et al. Neuroprotective effect of PACAP against NMDA-induced retinal damage in the mouse. J. Mol. Neurosci. 2011, 43, 22-29. [CrossRef]

75. Szabadfi, K.; Reglodi, D.; Szabo, A.; Szalontai, B.; Valasek, A.; Setalo, G., Jr.; Kiss, P.; Tamas, A.; Wilhelm, M.; Gabriel, R. Pituitary Adenylate Cyclase Activating Polypeptide, A Potential Therapeutic Agent for Diabetic Retinopathy in Rats: Focus on the Vertical Information Processing Pathway. Neurotox. Res. 2016, 29, 432-446. [CrossRef]

76. Gábriel, R.; Pöstyéni, E.; Dénes, V. Neuroprotective Potential of Pituitary Adenylate Cyclase Activating Polypeptide in Retinal Degenerations of Metabolic Origin. Front. Neurosci. 2019, 13, 1031. [CrossRef]

77. D'Amico, A.G.; Maugeri, G.; Reitano, R.; Bucolo, C.; Saccone, S.; Drago, F.; D'Agata, V. PACAP Modulates Expression of Hypoxia-Inducible Factors in Streptozotocin-Induced Diabetic Rat Retina. J. Mol. Neurosci. 2015, 57, 501-509. [CrossRef]

78. D’Amico, A.G.; Maugeri, G.; Rasà, D.M.; Bucolo, C.; Saccone, S.; Federico, C.; Cavallaro, S.; D'Agata, V. Modulation of IL-1 $\beta$ and VEGF expression in rat diabetic retinopathy after PACAP administration. Peptides 2017, 97, 64-69. [CrossRef]

79. Giunta, S.; Castorina, A.; Bucolo, C.; Magro, G.; Drago, F.; D’Agata, V. Early changes in pituitary adenylate cyclase-activating peptide, vasoactive intestinal peptide and related receptors expression in retina of streptozotocin-induced diabetic rats. Peptides 2012, 37, 32-39. [CrossRef]

80. Kvarik, T.; Mammel, B.; Reglodi, D.; Kovacs, K.; Werling, D.; Bede, B.; Vaczy, A.; Fabian, E.; Toth, G.; Kiss, P.; et al. PACAP is protective in a rat model of retinopathy of prematurity. J. Mol. Neurosci. 2016, 60, 179-185. [CrossRef]

81. Szabo, E.; Patko, E.; Vaczy, A.; Molitor, D.; Csutak, A.; Toth, G.; Reglodi, D.; Atlasz, T. Retinoprotective effects of PACAP eye drops in microbead-induced glaucoma model in rats. Int. J. Mol. Sci. 2021, 22, 8825. [CrossRef] [PubMed]

82. Szabadfi, K.; Atlasz, T.; Kiss, P.; Reglodi, D.; Szabo, A.; Kovacs, K.; Szalontai, B.; Setalo, G., Jr.; Banki, E.; Csanaky, K.; et al Protective effects of the neuropeptide PACAP in diabetic retinopathy. Cell Tissue Res. 2012, 348, 37-46. [CrossRef] [PubMed]

83. Fabian, E.; Reglodi, D.; Horvath, G.; Opper, B.; Toth, G.; Fazakas, C.; Vegh, A.G.; Wilhelm, I.; Krizbai, I.A. Pituitary adenylate cyclase activating polypeptide acts against neovascularization in retinal pigment epithelial cells. Ann. N. Y. Acad. Sci. 2019, 1455, 160-172. [CrossRef] [PubMed]

84. Maugeri, G.; D'Amico, A.G.; Saccone, S.; Federico, C.; Cavallaro, S.; D'Agata, V. PACAP and VIP Inhibit HIF-1 $\alpha$-Mediated VEGF Expression in a Model of Diabetic Macular Edema. J. Cell. Physiol. 2017, 232, 1209-1215. [CrossRef]

85. Maugeri, G.; D’Amico, A.G.; Gagliano, C.; Saccone, S.; Federico, C.; Cavallaro, S.; D'Agata, V. VIP Family Members Prevent Outer Blood Retinal Barrier Damage in a Model of Diabetic Macular Edema. J. Cell. Physiol. 2017, 232, 1079-1085. [CrossRef]

86. Mester, L.; Kovacs, K.; Racz, B.; Solti, I.; Atlasz, T.; Szabadfi, K.; Tamas, A.; Reglodi, D. Pituitary adenylate cyclase-activating polypeptide is protective against oxidative stress in human retinal pigment epithelial cells. J. Mol. Neurosci. 2011, 43, 35-43. [CrossRef]

87. Hannibal, J.; Ding, J.M.; Chen, D.; Fahrenkrug, J.; Larsen, P.J.; Gillette, M.U.; Mikkelsen, J.D. Pituitary adenylate cyclase-activating peptide (PACAP) in the retinohypothalamic tract: A potential daytime regulator of the biological clock. J. Neurosci. 1997, 17, 2637-2644. [CrossRef]

88. Bergström, A.L.; Hannibal, J.; Hindersson, P.; Fahrenkrug, J. Light-induced phase shift in the Syrian hamster (Mesocricetus auratus) is attenuated by the PACAP receptor antagonist PACAP6-38 or PACAP immunoneutralization. Eur. J. Neurosci. 2003, 18, 2552-2562. [CrossRef]

89. Elsås, T.; Uddman, R.; Sundler, F. Pituitary adenylate cyclase-activating peptide-immunoreactive nerve fibers in the cat eye. Graefe's Arch. Clin. Exp. Ophthalmol. 1996, 234, 573-580. [CrossRef]

90. Nakamachi, T.; Ohtaki, H.; Seki, T.; Yofu, S.; Kagami, N.; Hashimoto, H.; Shintani, N.; Baba, A.; Mark, L.; Lanekoff, I.; et al. PACAP suppresses dry eye signs by stimulating tear secretion. Nat. Commun. 2016, 7, 12034. [CrossRef]

91. Nilsson, S.F. PACAP-27 and PACAP-38: Vascular effects in the eye and some other tissues in the rabbit. Eur. J. Pharmacol. 1994, 253, 17-25. [CrossRef]

92. Tamada, Y.; Tanaka, M.; Ichitani, Y.; Okamura, H.; Yanaihara, N.; Ibata, Y. Pituitary adenylate cyclase-activating polypeptide (PACAP)-like immunoreactive neuronal elements in rat hypothalamus and median eminence with special reference to morphological background of its effect on anterior pituitary-light and electron microscopic immunocytochemistry. Neurosci. Lett. 1994, 180, 105-108. 
93. Lutz-Bucher, B.; Monnier, D.; Koch, B. Evidence for the presence of receptors for pituitary adenylate cyclase-activating polypeptide in the neurohypophysis that are positively coupled to cyclic AMP formation and neurohypophyseal hormone secretion. Neuroendocrinology 1996, 64, 153-161. [CrossRef]

94. Murase, T.; Kondo, K.; Otake, K.; Oiso, Y. Pituitary adenylate cyclase-activating polypeptide stimulates arginine vasopressin release in conscious rats. Neuroendocrinology 1993, 57, 1092-1096. [CrossRef]

95. Wang, Z.Y.; Alm, P.; Håkanson, R. Distribution and effects of pituitary adenylate cyclase-activating peptide in the rabbit eye. Neuroscience 1995, 69, 297-308. [CrossRef]

96. Yoshitomi, T.; Yamaji, K.; Ishikawa, H.; Ohnishi, Y. Effect of pituitary adenylate cyclase-activating peptide on isolated rabbit iris sphincter and dilator muscles. Investig. Ophthalmol. Vis. Sci. 2002, 43, 780-783.

97. Tajti, J.; Uddman, R.; Möller, S.; Sundler, F.; Edvinsson, L. Messenger molecules and receptor mRNA in the human trigeminal ganglion. J. Auton. Nerv. Syst. 1999, 76, 176-183. [CrossRef]

98. Shioda, S.; Takenoya, F.; Wada, N.; Hirabayashi, T.; Seki, T.; Nakamachi, T. Pleiotropic and retinoprotective functions of PACAP. Anat. Sci. Int. 2016, 91, 313-324. [CrossRef]

99. Maugeri, G.; Longo, A.; D’Amico, A.G.; Rasà, D.M.; Reibaldi, M.; Russo, A.; Bonfiglio, V.; Avitabile, T.; D’Agata, V. Trophic effect of PACAP on human corneal endothelium. Peptides 2018, 99, 20-26. [CrossRef]

100. Fukiage, C.; Nakajima, T.; Takayama, Y.; Minagawa, Y.; Shearer, T.R.; Azuma, M. PACAP induces neurite outgrowth in cultured trigeminal ganglion cells and recovery of corneal sensitivity after flap surgery in rabbits. Am. J. Ophthalmol. 2007, 143, 255-262. [CrossRef]

101. Dartt, D.A. Signal transduction and control of lacrimal gland protein secretion: A review. Curr. Eye Res. 1989, 8, 619-636. [CrossRef]

102. Wu, L.; Wang, J.; Chen, X.; Hong, A. Expression, identification and biological effects of the novel recombination protein, PACAP38-NtA, with high bioactivity. Int. J. Mol. Med. 2015, 35, 376-382. [CrossRef]

103. Il'inskiĭ, O.B.; Spevak, S.E.; Kochetkov, N.V.; Solov'eva, A.I.; Krasnikova, T.L. Participation of the lacrimal glands in wound healing processes. Bull. Exp. Biol. Med. 1985, 100, 91-93.

104. Shioda, S.; Takenoya, F.; Hirabayashi, T.; Wada, N.; Seki, T.; Nonaka, N.; Nakamachi, T. Effects of PACAP on Dry Eye Symptoms, and Possible Use for Therapeutic Application. J. Mol. Neurosci. 2019, 68, 420-426. [CrossRef]

105. Zhu, L.; Tamvakopoulos, C.; Xie, D.; Dragovic, J.; Shen, X.; Fenyk-Melody, J.E.; Schmidt, K.; Bagchi, A.; Griffin, P.R.; Thornberry, N.A.; et al. The role of dipeptidyl peptidase IV in the cleavage of glucagon family peptides: In vivo metabolism of pituitary adenylate cyclase activating polypeptide-(1-38). J. Biol. Chem. 2003, 278, 22418-22423. [CrossRef]

106. Kovacs, A.K.; Atlasz, T.; Werling, D.; Szabo, E.; Reglodi, D.; Toth, G.K. Stability Test of PACAP in Eye Drops. J. Mol. Neurosci. 2021, 71, 1567-1574. [CrossRef]

107. Ma, Y.; Zhao, S.; Wang, X.; Shen, S.; Ma, M.; Xu, W.; Hong, A. A New Recombinant PACAP-Derived Peptide Efficiently Promotes Corneal Wound Repairing and Lacrimal Secretion. Investig. Ophthalmol. Vis. Sci. 2015, 56, 4336-4349. [CrossRef]

108. Wang, Z.; Shan, W.; Li, H.; Feng, J.; Lu, S.; Ou, B.; Ma, M.; Ma, Y. The PACAP-derived peptide MPAPO facilitates corneal wound healing by promoting corneal epithelial cell proliferation and trigeminal ganglion cell axon regeneration. Int. J. Biol. Sci. 2019, 15, 2676-2691. [CrossRef]

109. Maugeri, G.; D’Amico, A.G.; Rasà, D.M.; Federico, C.; Saccone, S.; Morello, G.; La Cognata, V.; Cavallaro, S.; D’Agata, V. Molecular mechanisms involved in the protective effect of pituitary adenylate cyclase-activating polypeptide in an in vitro model of amyotrophic lateral sclerosis. J. Cell. Physiol. 2019, 234, 5203-5214. [CrossRef]

110. Moody, T.W.; Osefo, N.; Nuche-Berenguer, B.; Ridnour, L.; Wink, D.; Jensen, R.T. Pituitary adenylate cyclase-activating polypeptide causes tyrosine phosphorylation of the epidermal growth factor receptor in lung cancer cells. J. Pharmacol. Exp. Ther. 2012, 341, 873-881. [CrossRef]

111. Moody, T.W.; Lee, L.; Iordanskaia, T.; Ramos-Alvarez, I.; Moreno, P.; Boudreau, H.E.; Leto, T.L.; Jensen, R.T. PAC1 regulates receptor tyrosine kinase transactivation in a reactive oxygen species-dependent manner. Peptides 2019, 120, 170017. [CrossRef] [PubMed]

112. Maugeri, G.; D'Amico, A.G.; Bucolo, C.; D'Agata, V. Protective effect of PACAP-38 on retinal pigmented epithelium in an in vitro and in vivo model of diabetic retinopathy through EGFR-dependent mechanism. Peptides 2019, 119, 170108. [CrossRef] [PubMed]

113. Maugeri, G.; D’Amico, A.G.; Amenta, A.; Saccone, S.; Federico, C.; Reibaldi, M.; Russo, A.; Bonfiglio, V.; Avitabile, T.; Longo, A.; et al. Protective effect of PACAP against ultraviolet B radiation-induced human corneal endothelial cell injury. Neuropeptides 2020, 79, 101978. [CrossRef] [PubMed]

114. Wang, Z.Y.; Waldeck, K.; Grundemar, L.; Håkanson, R. Ocular inflammation induced by electroconvulsive treatment: Contribution of nitric oxide and neuropeptides mobilized from C-fibres. Br. J. Pharmacol. 1997, 120, 1491-1496. [CrossRef] [PubMed]

115. Wang, Z.Y.; Alm, P.; Håkanson, R. PACAP occurs in sensory nerve fibers and participates in ocular inflammation in the rabbit. Ann. N. Y. Acad. Sci. 1996, 805, 779-783. [CrossRef]

116. Vizzard, M.A. Up-regulation of pituitary adenylate cyclase-activating polypeptide in urinary bladder pathways after chronic cystitis. J. Comp. Neurol. 2000, 420, 335-348. [CrossRef]

117. Sundrum, T.; Walker, C.S. Pituitary adenylate cyclase-activating polypeptide receptors in the trigeminovascular system: Implications for migraine. Br. J. Pharmacol. 2018, 175, 4109-4120. [CrossRef]

118. Mehta, D.; Granstein, R.D. Immunoregulatory Effects of Neuropeptides on Endothelial Cells: Relevance to Dermatological Disorders. Dermatology 2019, 235, 175-186. [CrossRef] 